\title{
Prospective directions of state regulation of "green" energy development in the context of Ukraine's energy safety
}

\author{
Oleksandr Radchenko ${ }^{1,2}$, Oksana Radchenko ${ }^{3}$, Oleksiy Kriukov ${ }^{4}$, Valeriia Kovach $^{2,5,}$, Oleksii Mykhalchenko ${ }^{2}$, \\ Rovshan Abbasov ${ }^{6}$, and Virginija Jureniene ${ }^{7}$ \\ ${ }^{1}$ Hryhoriy Skovoroda University in Pereiaslav, 30 Sukhomlynsky Str., Pereiaslav, 08401, Ukraine \\ ${ }^{2}$ National Aviation University, 1 Liubomyra Huzara Ave., Kyiv, 03058, Ukraine \\ ${ }^{3}$ Interregional Academy of Personnel Management, 2 Frometivska Str., Kyiv, 03039, Ukraine \\ ${ }^{4}$ National University of Civil Protection, 94 Chernyshevska Str., Kharkiv, 61023, Ukraine \\ ${ }^{5}$ State Institution "The Institute of Environmental Geochemistry of National Academy of Sciences of Ukraine", \\ 34a Palladin Ave., Kyiv, 03142, Ukraine \\ ${ }^{6}$ Kazar University, 41 Mehseti Str., Baku, AZ1008, Azerbaijan \\ ${ }^{7}$ Vilnius University, 8 Muitines Str., Kaunas, LT-44280, Lithuania
}

\begin{abstract}
The article describes the leading world trends and factors of state regulation of "green" energy development as a key element of energy safety of mankind at transition stage to globalized society. Paradigm change of energy safety of mankind, problems and obstacles on the way to abandon hydrocarbons use as the main energy sources and replace them by renewable environmentally friendly sources are analyzed. International and national normative legal documents regulating functioning and "green" energy development are characterized. Mechanisms for strengthening Ukraine's energy safety by acceleration stimulating of construction of new generation power plants using exclusively renewable energy sources in our country were proposed.
\end{abstract}

\section{Introduction}

The modern world is characterized by two interrelated global phenomena: level of energy consumption and level of environmental pollution. Ozone holes in the atmosphere, entire continents of floating wastes in the ocean, emissions of carbon and other harmful substances at the present stage of human development are acute issues of human existence safety.

Today, it is clear that focus on hydrocarbon energy sources - coal, oil, gas - as dominant in energy production, has exhausted itself and can lead to death of humanity. Oil and gas economy reached its historical impasse. Global problems of economic, energy and environmental safety of all mankind and the vast majority of countries around the world are interconnected. It is especially felt in modern Ukraine, where the war in Donbass demonstrated all helplessness of the national economy with its almost dominant energy dependence on the aggressor country (at the level of $60 \%$ [1]). Yes, Russian aggression exposed all problems of energy safety of our country. It forced the Ukrainian government to start reforms to diversify energy sources, but these measures are unsystematic and insufficient. Level of their implementation does not meet today's challenges. It is evidenced by at least such shameful statistics for us, given in December 2018 by the authoritative financial analytical center "Carbon Tracker" (Fig. 1): heat generation in Ukraine is the most inefficient and most expensive in the world (the cost is higher than
European Union prices by $40 \%$ and from the Russian Federation by $75 \%$ !) [2,3]. Therefore, it is important to study the world's advanced approaches, mechanisms and tools of state regulation of "green" energy development as a key element of energy safety.

Issue of world energy modernization in the direction of gradual abandonment of hydrocarbons and transition to environmentally friendly renewable energy sources as a guarantee of further energy, economic and environmental safety of mankind was debated in scientific discourse of the early XXI century. In particular, among recent publications in this field it is worth noting such foreign researchers as Born [4], Sopian and Khan [5], Mateus and Tan [6], Nahi [7], Kherbs and Frih [8], Tvidell [9]. A number of important issues regarding the functioning of energy facilities and their impact on the environment are disclosed in articles [10-24]. In recent years, in Ukraine following scientists have researched issue of "green" energy development: Benedyk [25], Bila [26], Herasymchuk [27], Kudria [28], Kuzmina [1, 29], Lehka [30], Prokip [31], Riazanova [32], Stoian [33], Tkachuk, Rechun and Priadko [34], Trofymenko [35], Cherniak [31] and other. We will try to generalize their scientific achievements in this article.

The research aim is to analyze and summarize the world's leading trends and factors of state regulation of "green" energy development as a key element of energy safety of mankind at stage of transition to a globalized society.

\footnotetext{
Corresponding author: valeriiakovach@gmail.com
} 


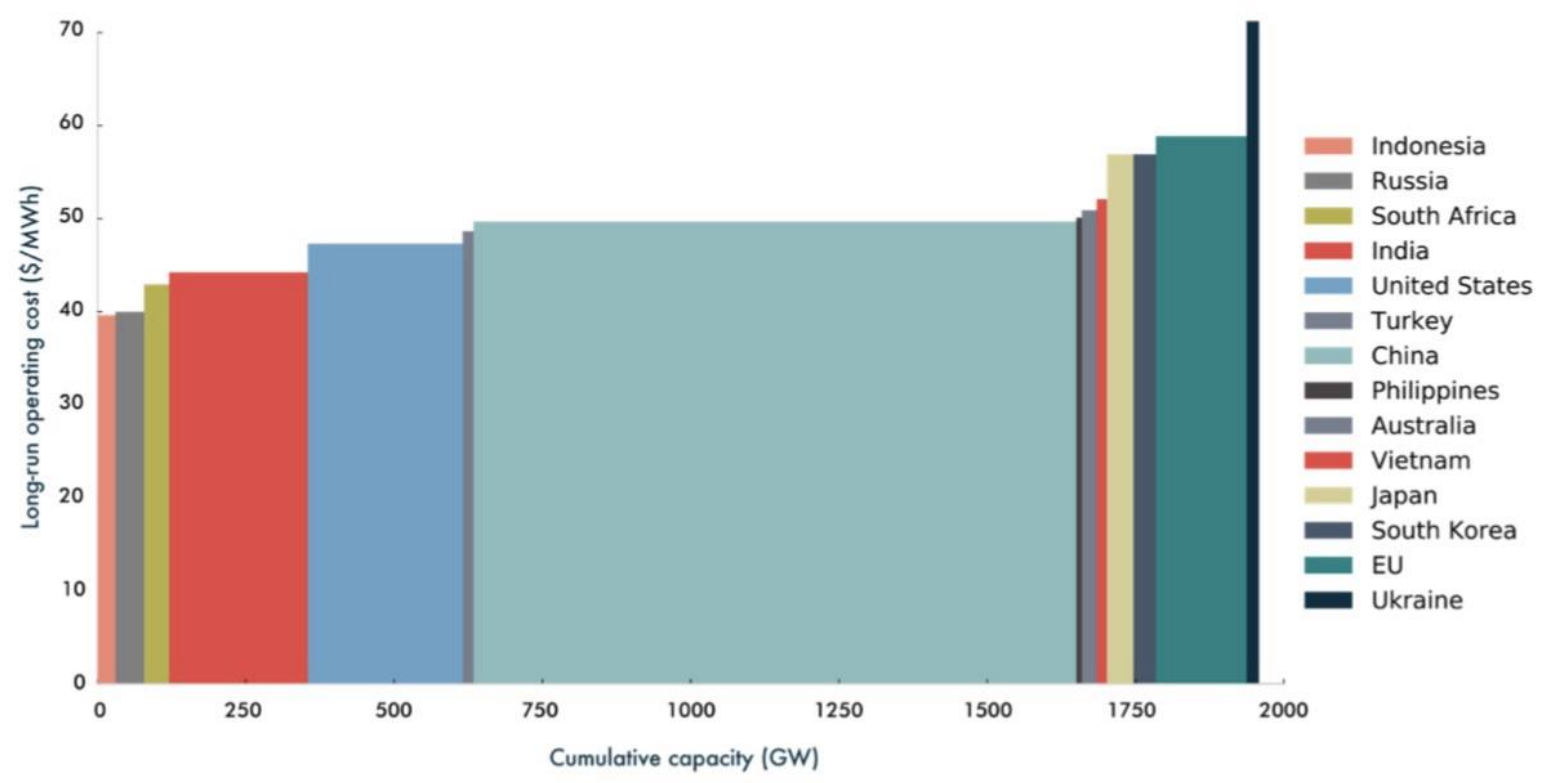

Source: Carbon Tracker analysis

Notes: long-run operating costs include fuel, carbon where applicable, variable O\&M, fixed O\&M and any capital additions from meeting environmental regulations. 2018 fuel costs are based on monthly or daily price averages, while from 2019 onwards we take an annual average from 2014 to 2017.

Fig. 1. Global long-run operating cost curve of coal capacity existing and under construction [3].

\section{Results}

Beginning of the third millennium was marked by transition to new energy policy of the world's leading states and international community capable to ensure sustainable development and energy, environmental and economic future. J. Bjorn said that states and governments need to make difficult choices in the shortest possible time and these government decisions will forever change not only energy and economy, but also environmental, social, cultural, etc. living conditions of mankind [4].

According to Stoyan transition to green economy and Ukraine's integration into the world energy space given need to form effective system of mechanisms for state regulation of renewable energy development in our country [33]. This opinion is shared, in particular, by A. Prokip. He is convinced that in this case the cumulative effect of developing measures to ensure energy and national safety, in addition to minimizing the country's dependence on energy suppliers and concern for the environment, will reduce social tensions [31].

It should be noted that given existing disparities in needs and opportunities for obtaining fuel energy resources, there are four models of energy safety:

1. Model of guaranteed energy safety (is typical for countries that are not only able to fully meet their own energy problems, but also have their significant reserves for sale: UAE, Venezuela, Russia, other OPEC countries);

2. Model of self-sufficient energy safety (typical for countries whose own energy resources are sufficient for domestic needs, but not enough for exports, e.g. India);

3. Model of insufficient energy safety (typical for countries whose energy needs require import of energy and measures aimed at diversifying energy sources, stimulating the introduction of alternative energy technologies. Such countries include the EU, Ukraine, etc.).

4. Model of crisis energy security (when a country is forced to import more than $50 \%$ of the required amount of energy, e.g. Japan).

The European Union's policy on energy supply safety in the European energy space due to the EU countries among the third group of countries with insufficient energy security is formed in several directions with the main goal - to accelerate transition to the second group (self-sufficiency) obtaining and consuming the necessary energy. M. Kuzmina names following components of the EU energy security system: energy saving and energy efficiency, diversification of energy resources both own and imported (natural gas, coal, oil, RES) [1].

What is the key difference between a traditional economy and a "green" one? Traditional economy was based on use of non-renewable energy sources such as wood, coal, oil and gas. According to N. Riazanov generation of fossil fuel-based electricity was the most important driver of economic development since the beginning of the industrial revolution. Environmental consequences of this development were not taken into account for a long time, until nature declared itself: rising world temperatures, rising sea levels, ocean pollution and other effects of climate change began to seriously affect coastal areas and coastal countries. Existence of many communities and biological life support systems on the planet was threatened. Growing negative effects of climate change increasingly led to the realization that if you follow the previous course of development without taking into account environmental imperatives it will lead to catastrophic consequences [32]. 
So-called "green economy" (term of journalistic nature) or "alternative energy economy" (scientific publications also have another synonymous definition "energy economy based on renewable energy sources") abandons dominance of non-renewable hydrocarbon resources in favor of virtually endless sources. Renewable energy sources (RES) include wind and solar energy (wind and solar power plants); aero-, geo- and hydrothermal (heat extraction from atmospheric air, from the surface of the earth and from the surface waters of terrestrial reservoirs); river, tidal and ocean energy (small hydropower, tidal power plants); biomass and biogas (biological share of products, waste and residues of biological origin from agriculture, including plant and animal substances, forestry and related industries, including fisheries and aquaculture, as well as the biological part of industrial and domestic waste; gas from organic waste, gas from treated wastewater, etc.).

Key advantages of renewable energy sources are their environmentally friendly nature, practical inexhaustibility of stocks over historically long period, availability of modern energy services in rural areas, climate change mitigation, promoting "green jobs" and improving quality of life. That is why J. Matheus and H. Tan call renewable energy technologies one of the most important strategies in addressing sustainable development of mankind [6]. In order to set large-scale tasks and develop new markets O. Chernyak notes international cooperation and active investment in RES by all countries of the world are necessary. The use of RES worldwide is an important step towards stable future for all mankind [36].

It is no coincidence that these issues are periodically raised and important political and legal decisions are made regarding the transition of mankind to energy based on renewable energy sources (RES) at the planetary level.
Thus, at the Paris Climate Conference on November 30, 2015, 100 of the 195 participating countries (including Ukraine) supported the decision to move to 2050 for the full use of renewable energy sources [36]. However, the commitments are quite divergent, especially in terms of the pace of such a transition. For example, Ukraine, as a member of European Energy Community made the lowest commitment to increase the share of RES in the country's energy balance by only $11 \%$ by 2020 (and the current situation shows that Ukraine will not reach half of the planned), while Switzerland plans to have $49 \%$ of renewable energy in 2020, Latvia - 40\% Finland - 38\% Austria - 34\%.

Fig. 2 shows the breakdown of primary energy that is shown based on the 'substitution' method which takes into account inefficiencies in energy production from fossil fuels. Particular one is based on the global energy production for 2019 year. It can be seen that in 2019, almost $16 \%(15.7 \%$ if to be precise) of global primary energy came from low-carbon sources. Low-carbon sources are the sum of nuclear energy and renewables which includes hydropower, wind, solar, bioenergy, geothermal and wave and tidal [38]. 11.4\% came from renewables; and $4.3 \%$ came from nuclear. Hydropower and nuclear account for most of our low-carbon energy: combined they account for $10.7 \%$. Wind produces just $2.2 \%$, and solar $1.1 \%$ - but both sources are growing quite rapidly. Despite producing more and more energy from renewables each year, the global energy mix is still dominated by coal, oil, and gas. Not only does most of our energy $-84 \%$ out of it - come from fossil fuels, we continue to burn more each year: total production has increased from 116,214 to $136,761 \mathrm{TWh}$ in the last 10 years [37].

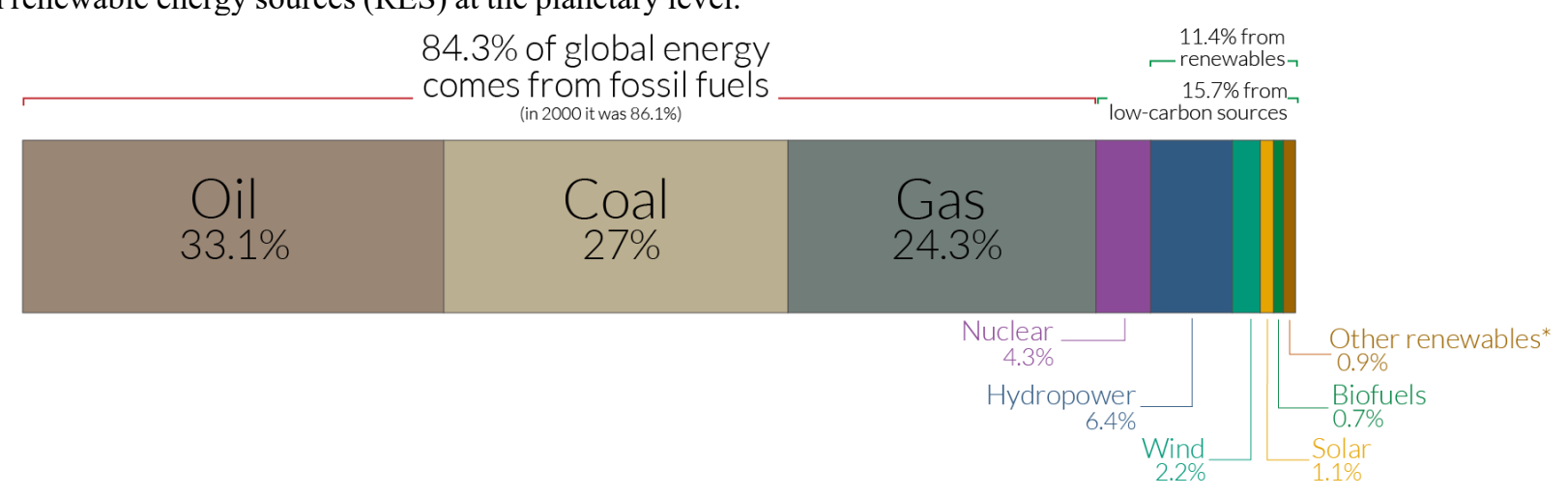

*'Other renewables' includes geothermal, biomass, wave and tidal. It does not include traditional biomass which can be a key energy source in lower income settings. OurWorldinData.org - Research and data to make progress against the world's largest problems.

Source: Our World in Data based on BP Statistical Review of World Energy (2020).

Fig. 2. Global primary energy consumption by source [37].

Numerous international and intergovernmental organizations coordinating in the field of "green energy" were established. International Energy Agency, established in 1974, is the central intergovernmental institution in the field of energy in addition to aforementioned European Energy Community. Initially, the organization was created to consolidate efforts of developed countries to maintain their own energy safety. Today, as J. Benedyk notes, this agency is at the heart of global energy dialogue, providing authoritative statistical reports, analyzes and recommendations, focusing on four areas, the so-called " 4 ":

- energy safety - by promoting diversification, efficiency and flexibility in all energy sectors;

- economic development - by ensuring stable energy supplies to member countries and free markets development to stimulate economic growth and eliminate energy poverty;

- environmental awareness - through analysis of possible policy decisions and measures to compensate 
negative impact of energy production and consumption on the environment and climate change;

- global engagement worldwide - by ensuring close cooperation with countries that are not members of the IEA, especially with the largest producers and consumers, to find solutions to common energy and environmental problems [25].

B. Nagy in the book "The Age of Clean Energy" prioritizes following among the main areas of institutional support for international economic cooperation in the development of renewable energy: organization of international consultations on framework programs development for use of renewable energy; promoting development of technology and knowledge transfer in the field of renewable energy; creation of regional centers for research, development and exchange of experience in the field of renewable energy development; dissemination promoting of successful world experience in the renewable energy use; planning of financial support of renewable energy sources (RES) programs; collection and processing of statistical data in the field of renewable energy development; monitoring and adjustment of plans (strategies) for renewable energy development [7].

An important place in transition regulating to "green energy" dominance is occupied by state, interstate and international programs to stimulate research, technological and practical developments in the field of RES. Thus, S. Bila notes that the EU countries are characterized by such incentives use that facilitate transition from traditional to renewable energy: tariff benefits ("green" tariffs - FITs, and "green" surcharges FIPs); quotas regulation on electricity production and use of "green certificates" system sold on the market and promote the attraction of free investment funds in the field of renewable energy (TGC); soft loans, grants and credit guarantees, government subsidies and investment grants [26].

Positive results are observedt. In particular, share of renewable electricity in the German economy is growing steadily. If in 2000 share of German RES was $7 \%$, then in $2010-17 \%$, by 2020 this figure will increase to $35 \%$ and in 2050 - up to $80 \%$. However, the world leader is already China and, according to J. Matheus and H. Tang, this leadership will only grow due to the huge public investment in the renewable energy sector [6].

The director of the Institute of Renewable Energy of the National Academy of Sciences of Ukraine, Doctor of Technical Sciences S. Kudria, claims that our country has all prerequisites for large-scale development of technologies based on renewable energy sources. First of all, it has significant energy potential (wind, solar energy, small river energy, biomass, geothermal energy and environmental energy), as well as a developed scientific, technical and industrial base. In addition, the key factors in the development of RES in Ukraine are need to improve environmental situation; exhaustion of traditional fuel and energy resources; urgent need to overcome dependence on energy imports; international obligations; need for urgent renovation of fixed assets of energy equipment in the country. This industry is one of the most attractive for investment [28]. V. Gerasymchuk and O. Romanyuk estimated annual potential of Ukraine's renewable energy at 100-110 million tons. In particular, average annual potential of solar energy in Ukraine exceeds average of countries such as Poland and Germany. It determines significant prospects for use of solar panels in Ukraine. Also, one of the most promising and investment-attractive areas in Ukrainian alternative energy is production of solid biofuels. Characteristic feature of solid biofuel market is the significant demand for products in the European Union, which made the industry exportoriented [27].

However, process of development of renewable energy in Ukraine is very slow despite significant potential. Share of energy produced from renewable sources in total energy at the end of 2017 was only about $2 \%$ [24].

Fig. 3 shows energy consumption by source in Ukraine [37]. Primary energy consumption is measured in terawatt-hours (TWh). An inefficiency factor (the 'substitution' method) has been applied for fossil fuels, meaning the shares by each energy source give a better approximation of final energy consumption.

This situation requires urgent measures of state stimulation of "green energy" sector development in Ukraine. Among such measures O. Cherniak names:

- exemption from profits taxation of companies that produce electricity only from RES;

- introduction of "green" tariff;

- land tax reduction for enterprises using renewable energy;

- exemption from import duties when importing certain types of equipment for renewable energy;

- exemption from taxation of operations on import of certain types of equipment for renewable energy [36].

K. Lehka also offers at state level:

- to increase attractiveness of those RES development that have high probability of economic payback in future and are the most promising in terms of production in Ukraine;

- to support development and implementation of competitive technologies;

- to stimulate localization of production and the necessary equipment [30].

In turn, O. Trofimenko groups tools for implementing of state regulation mechanism of strategic development of renewable energy into three main parts:

- fiscal (preferential tariffs, government spending, income tax, financial instruments for the regulation of renewable energy);

- organizational (rules, organizational, legal norms and standards that determine state regulation of renewable energy, duties, rights and responsibilities of state regulators, organization of their activities, including organization of fiscal tools to implement the mechanism of state regulation of strategic development of renewable energy);

- methodical (set of measures to improve methodology of selection of renewable energy projects, methodological approaches to assessing the level of development of renewable energy, energy saving potential, study of the status and ranking of regions and industries by energy security, system of measures for renewable energy development at the methodological level) [35]. 


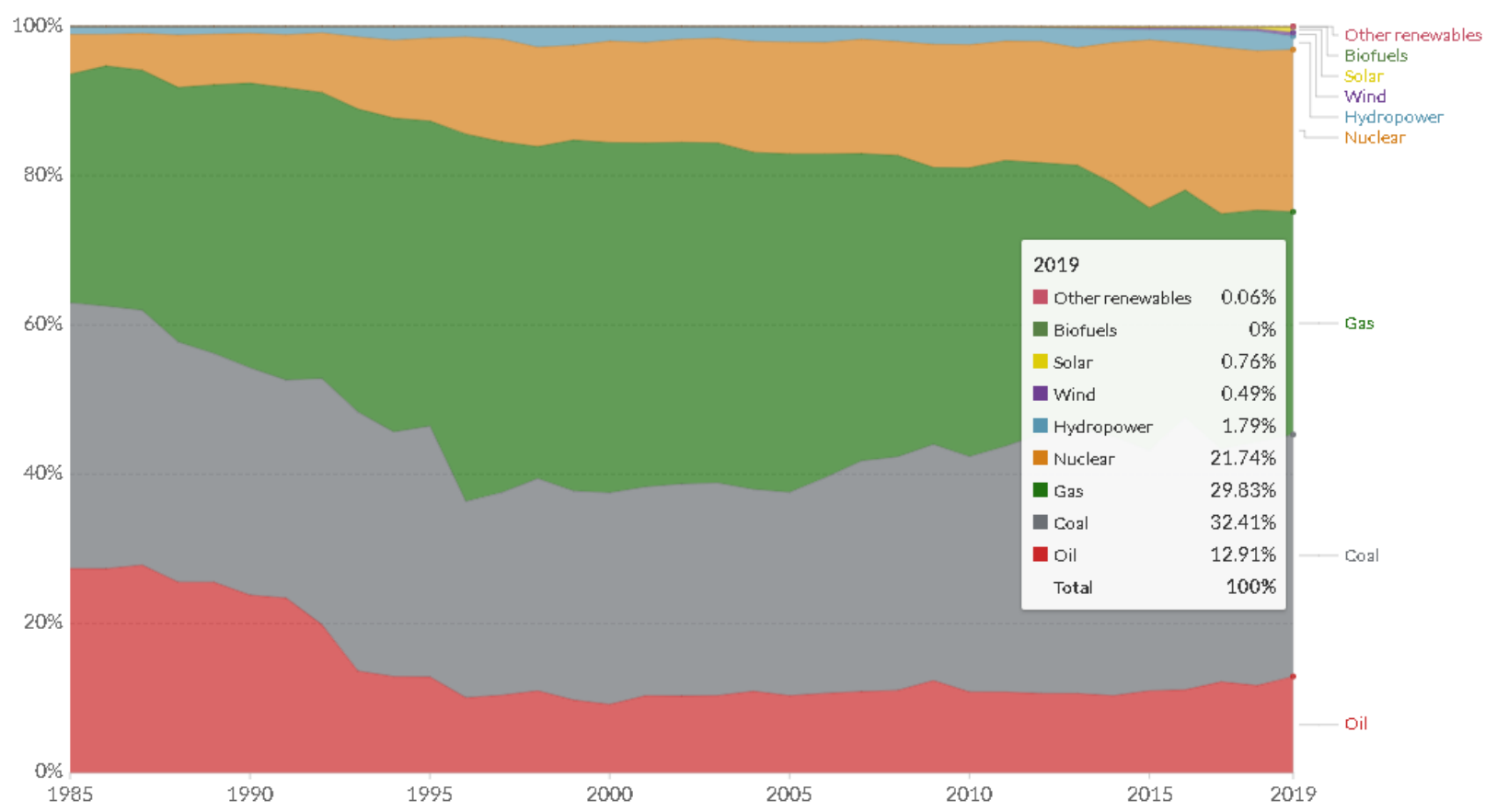

Fig. 3. Energy consumption by source, Ukraine [37].

According to V. Tkachuk, O. Rechun and O. Pryadko following measures can provide prospects for renewable energy development in Ukraine:

- energy safety level increasing of Ukraine by diversifying and depoliticizing supply of energy resources;

- burden reducing on the environment;

- environmental awareness raising of Ukrainian citizens, because "green" energy is not only improving environment, but preserving human health and prolonging life on Earth [34].

Thus, in the course of our research we identified leading trends of interstate and state regulation of green energy as a key element of mankind energy safety in the transition to a globalized society. They are embedded in the global strategy of human civilization through abandonment of hydrocarbons in favor of renewable energy.

\section{Conclusions}

Thus, we can conclude that rapid depletion of natural traditional energy resources on the planet and their constant price rise in the face of growing human needs for electricity will inevitably lead to rapid replacement of hydrocarbon economy by "green economy" based on renewable energy sources [39]. The world's leading countries actively develops alternative energy as a factor in energy safety improving. It improves environment, increases standard and quality of life.

Ukraine should to develop and actively implement new energy strategy based on effective state regulators and aimed at diversifying energy dependence on Russia and a gradual transition to the dominance of renewable energy sources. Our state should provide comprehensive legal, fiscal, tax, financial, informational and organizational support for creation and use of energy power plants, grant and investment support for scientific and technological developments in this area.

\section{References}

1. M.M. Kuzmina, Development of renewable energy as a guarantee of energy country's security. Economic theory of law 3, 85-95 (2017)

2. Ekonomichna pravda, Heat generation in Ukraine has been called the most inefficient and most expensive in the world. https://www.epravda.com.ua/news/2018/12/3/64321 8. Accessed 27 Dec 2020

3. Powering down coal, Navigating the economic and financial risks in the last years of coal power (2018). https://carbontracker.org/. Accessed 27 Dec 2020

4. J. Byrne, Green Energy Economies: The Search for Clean and Renewable Energy (Routledge, 2017).

5. C. Hoy-Yen, S. Kamaruzzaman, Renewable Energy in Developing Countries: Local Development and Techno-Economic Aspects (Springer International Publishing, 2018)

6. John A. Mathews, Hao Tan, China's Renewable Energy Revolution (Palgrave Pivot, London, 2015)

7. B.F. Nagy, The Clean Energy Age: A Guide to Beating Climate Change (Rowman \& Littlefield Publishers, 2018)

8. C. Herbes, C. Frieg, Marketing Renewable Energy: Concepts, Business Models and Cases (Springer International Publishing, 2018)

9. J. Twidell, Renewable Energy Resources (Routledge, 2015)

10. A. Iatsyshyn, A. Iatsyshyn, V. Artemchuk, I. Kameneva, V. Kovach, O. Popov, Software tools for tasks of sustainable development of environmental 
problems: peculiarities of programming and implementation in the specialists' preparation. E3S Web Conf. 166, $01001 \quad$ (2020). doi:10.1051/e3sconf/202016601001

11. A.O. Zaporozhets, V.V. Khaidurov, Mathematical Models of Inverse Problems for Finding the Main Characteristics of Air Pollution Sources. Water, Air, Soil Pollut. 231, 563 (2020). doi:10.1007/s11270020-04933-z

12. M.L. Myrontsov, Multi-Probe Hardware for Electrometry of Oil and Gas Wells, Science and innovation $\quad \mathbf{1 4}(3), \quad 51-56 \quad$ (2018). doi: $15407 /$ scine 14.03 .051

13. O. Mandryk, N. Moskalchuk L. Arkhypova, M. Prykhodk, O. Pobigun. Prospects of environmentally safe use of renewable energy sources in the sustainable tourism development of the Carpathian region of Ukraine. E3S Web Conf. 166, 04005 (2020). doi:10.1051/e3sconf/202016604005

14. Y. Kyrylenko, I. Kameneva, O. Popov, A. Iatsyshyn, V. Artemchuk, V. Kovach, Source Term Modelling for Event with Liquid Radioactive Materials Spill, in Studies in Systems, Decision and Control, vol. 298, ed. by V. Babak, V. Isaienko, A. Zaporozhets (Springer, Cham, 2020), pp. 261-279. doi:10.1007/978-3-030-48583-2_17

15. O. Maevsky, V. Artemchuk, Y. Brodsky, I. Pilkevych, P. Topolnitsky, Modeling of the Process of Optimization of Decision-Making at Control of Parameters of Energy and Technical Systems on the Example of Remote Earth's Sensing Tools, in Studies in Systems, Decision and Control, vol. 298, ed. by V. Babak, V. Isaienko, A. Zaporozhets (Springer, Cham, 2020), pp. 111-122. doi:10.1007/978-3-030-48583$2+7$

16. O. Akimov, M. Karpa, C.V. Dubych, D. Zayats, N. Movmyga, N. Tverdokhliebova, Determination of requirements for protection of radio-electronic means of security management of particularly important state energy facilities from the destructive impact of electromagnetic, International Journal of Emerging Trends in Engineering Research, 8(9), 6214-6219 (2020)

17. O. Maliarenko, V. Horskyi, V. Stanytsina, O. Bogoslavska, H. Kuts, An Improved Approach to Evaluation of the Efficiency of Energy Saving Measures Based on the Indicator of Products Total Energy Intensity, in Studies in Systems, Decision and Control, vol. 298, ed. by V. Babak, V. Isaienko, A. Zaporozhets (Springer, Cham, 2020), pp. 201-216. doi:10.1007/978-3-030-48583-2_13

18. O. Bogoslavska, V. Stanytsina, V. Artemchuk, O. Garmata, V. Lavrinenko, Comparative Efficiency Assessment of Using Biofuels in Heat Supply Systems by Levelized Cost of Heat into Account Environmental Taxes, in Studies in Systems, Decision and Control (Springer, Cham, 2021 to be published)

19. O.M. Mandryk, L.M. Arkhypova, O.V. Pobigun, O.R. Maniuk, Renewable energy sources for sustainable tourism in the Carpathian region. IOP Conf. Ser.: Mater. Sci. Eng. 144, 012007 (2016). doi:10.1088/1757-899X/144/1/012007

20. T. Yatsyshyn, N. Glibovytska, L. Skitsa, M. Liakh, S. Kachala, Biotechnogenic System Formed by LongTerm Impact of Oil Extraction Objects, in Studies in Systems, Decision and Control, vol. 298, ed. by V. Babak, V. Isaienko, A. Zaporozhets (Springer, Cham, 2020), pp. 165-177. doi:10.1007/978-3-030-485832_11

21. L. Akimova, O. Akimov, T. Maksymenko, Z. Hbur, V. Orlova, Adaptive management of entrepreneurship model as a component of enterprise resource planning. Academy of Entrepreneurship Journal, 26(3), 1-8 (2020)

22. V. Gurieiev, Yu. Kutsan, A. Iatsyshyn, A. Iatsyshyn, V. Kovach, E. Lysenko, V. Artemchuk, O. Popov, Simulating Systems for Advanced Training and Professional Development of Energy Specialists in Power Sector. CEUR Workshop Proceedings 2732, 693-708 (2020). http://ceur-ws.org/Vol2732/20200693.pdf. Accessed 29 Nov 2020

23. V. Mokhor, S. Gonchar, and Dybach O., Methods for the Total Risk Assessment of Cybersecurity of Critical Infrastructure Facilities, Nucl. Radiat. Saf. 2(82), (2019) 4-8. doi:10.32918/nrs.2019.2(82).01

24. O. Popov, A. Iatsyshyn, V. Kovach, V. Artemchuk, I. Kameneva, D. Taraduda, V. Sobyna, D. Sokolov, M. Dement, T. Yatsyshyn, Risk assessment for the population of Kyiv, Ukraine as a result of atmospheric air pollution. J. Health Pollut. 10, 200303 (2020). doi:10.5696/2156-961410.25.200303

25. Y. Benedyk, International Energy Agency in the organizational mechanism of cooperation of states in the field of renewable energy. Pidpryyemnytstvo, hospodarstvo i pravo 3, 171-176 (2016)

26. S.O. Bila, Institutional support for international economic cooperation in the field of renewable energy. Ekonomichnyy visnyk universytetu 37(1), 267-275 (2018)

27. V.H. Herasymchuk, Trends in the development of renewable energy in the world and in Ukraine. Naukovyy visnyk Mizhnarodnoho humanitarnoho universytetu 14, 4-8 (2015)

28. S.O. Kudrya, Status and prospects of renewable energy development in Ukraine. Visn. Nac. Acad. Nauk Ukr. 12, 19-26 (2015)

29. M. M. Kuz'mina, Legal features of the functioning of renewable energy facilities. Ekonomichna teoriya ta pravo 2, 136-148 (2018)

30. K. V. Lehka, Prospects for the development of green energy in Ukraine. Bulletin of the National university of water and environmental engineering (Economy) 1, 138-146 (2013)

31. A.V. Prokip, Role of renewable energy in achieving energy security sustainability. Bulletin of the 
National university of water and environmental engineering (Economic sciences) 1, 79-93 (2016)

32. N.O. Ryazanova, Renewable energy sources in the process of global energy transformation. Bulletin of Odessa National University 6, 70-75 (2017)

33. O.Yu. Stoyan, World and domestic experience in the implementation of mechanisms of state regulation of renewable energy: the main trends and prospects. Naukovi pratsi Chornomors'koho derzhavnoho universytetu imeni Petra Mohyly kompleksu "Kyyevo-Mohylyans'ka akademiya” 223, 94-100 (2014)

34. V.V. Tkachuk, O.Yu. Rechun, O.A. Pryadko, "Green Energy": the experience of Germany and Ukrainian realities. Tovaroznavchyy visnyk 10, 153-161 (2017)

35. O. Trofymenko, Varieties of state and supranational regulation of renewable energy. Ekonomichnyy analiz 12(1) 292-298 (2013)

36. O.I. Chernyak, Ya.V. Farenyuk, A study of the amount of investment in the "green energy" of the world. Bulletin of Taras Shevchenko National University of Kyiv (Economics) 12, 59-67 (2015)

37. H. Ritchie. Energy mix. https://ourworldindata.org/energy-mix. Accessed 27 Dec 2020

38. S. Schlömer, T. Bruckner, L. Fulton, E. Hertwich, A. McKinnon, D. Perczyk, J. Roy, R. Schaeffer, R. Sims, P. Smith, and R. Wiser, Annex III: Technology-specific cost and performance parameters, in Climate Change 2014: Mitigation of Climate Change. Contribution of Working Group III to the Fifth Assessment Report of the Intergovernmental Panel on Climate Change (Cambridge University Press, Cambridge, United Kingdom and New York, NY, USA, 2014)

39. S. Semerikov, S. Chukharev, S. Sakhno, A. Striuk, V. Osadchyi, V. Solovieva, T. Vakaliuk, P. Nechypurenko, O. Bondarenko, H. Danylchuk, Our sustainable coronavirus future. E3S Web Conf. 166, 00001 (2020). 